IN OUR LIBRARIES

\title{
A Tribute to Wojciech Zalewski on His Retirement
}

\author{
Patricia Polansky \\ Janet I. Crayne \\ Leon Ferder \\ Janet Zmroczek \\ Marianna Tax Choldin \\ Compiled by Karen Rondestvedt
}

Wojciech Zalewski, Curator for Slavic and East European Collections at Stanford University Libraries, retired on April 1, 1999, after twenty-eight years of distinguished service to Slavic librarianship, both in the United States and in the wider world. The selections below

Patricia Polansky is Russian Bibliographer, Hamilton Library, University of Hawaii, 2550 The Mall, Honolulu, HI 96822, USA. Janet I. Crayne is Senior Associate Librarian, Slavic Division, $111 \mathrm{G}$ Hatcher Graduate Library North, University of Michigan, Ann Arbor, MI 48109-1205, USA. Leon Ferder is Slavic and East European Bibliographer, Young Research Library, UCLA, Box 951575, Los Angeles, CA 90095-1575, USA. Janet Zmroczek is affiliated with The British Library, Slavonic and East European Collections, 96 Euston Road, London NW1 2DB, UK. Marianna Tax Choldin, a member of SEEIR's editorial board, is Director, C. Walter and Gerda B. Mortenson Center for International Library Programs, and Mortenson Distinguished Professor, University of Illinois Library at Urbana-Champaign, $246 \mathrm{~J} \mathrm{Li}$ brary, 1408 West Gregory Drive, Urbana, IL 61801, USA.

Slavic \& East European Information Resources, Vol. 1(1) 2000

(c) 2000 by The Haworth Press, Inc. All rights reserved. 
represent a sampling of the high esteem in which Dr. Zalewski is held by his colleagues in the English-speaking world. If I (KR) had cast my net wider, into Russia and Poland in particular, I have no doubt that the responses would have been equally enthusiastic. It is truly gratifying to be able to present the tributes here, from respected colleagues, to someone whom I, too, consider both a mentor and a friend.

Gordon Anderson, of the University of Kansas Libraries, writes, "Wojciech: In the midst of all your fine work in Russian reference, you did not forget Poland. I will always remember with fondness your unique contributions to Polish-studies librarianship, and support for all your colleagues. Best wishes, Gordon Anderson."

\section{FROM PATRICIA POLANSKY:} AT THE FEET OF A CURATOR

As one of the representatives of a much smaller, specialized Russian collection, I have always relied on my colleagues at the larger libraries with Slavic holdings for help. Wojciech Zalewski has for twenty-four years been a steady source of advice and support, both professionally and personally. He has always been most generous with his time, expertise and encouragement; a hard worker, conscientious and perceptive. His presence will be sorely missed in this computerized age that is sweeping us away from the world of books.

As an outstanding contributor to Slavic librarianship, Dr. Zalewski presents an impressive list of accomplishments. He was always an active participant in the American Association for the Advancement of Slavic Studies (AAASS), usually on one or more panels at each convention; he was a member of the association's Bibliography \& Documentation Committee, the librarians' leadership group. He often participated in the Western Slavic Association meetings. Within the American Library Association he was active for many years in the Association of College \& Research Libraries' Slavic and East European Section (ACRL/SEES), where he began the annual newsletter in 1985, which is still being issued. While working with this group he also worked on a handbook for prospective Slavic librarians.

We are all in Wojciech's debt for his scholarly contributions to Slavic librarianship. The most important one for me was his annual bibliographical survey in Russian Review, which he did from 1975 to 1986. I also heavily relied on his Russian English Dictionaries With 
Aids for Translators (1981) and Fundamentals of Russian Reference Work in the Humanities and Social Sciences (1985). The latter title is now available on the Web <http://www-sul.stanford.edu/depts/hasrg/ slavic/3refint.html>. Scholars, as well as librarians, appreciated his Collectors and Collections of Slavica at Stanford University, a contribution to the history of American academic libraries (1985), which recounted, among others, the important work of Alexis Babine and Frank Golder. For my own research, which concerns the Russian emigration in Asia, the publication of Dealers of Polish and Russian Books Active Abroad, 1918 to Present: a contribution to the history of the book trade (1990), was most welcome.

Wojciech was closely connected with the book studies world in Moscow and St. Petersburg. He was invited to many conferences. Our Russian colleagues have also recognized Wojciech's contributions; see, for example, "Trudno predstavit' mir bez bibliografov," Bibliografiia 3 (283) (1997): 120-125. And one of Wojciech's most poignant descriptions is his friendship with Victor Kharlamov, whose life ended too early ("Pamiati Viktora Ivanovicha Kharlamova, (1948-1996), Istorikobibliograficheskie issledovaniia: sbornik nauchnykh trudov 1998, vyp. 7: 189-191).

Although Dr. Zalewski is fluent in many languages, naturally his greatest affinity was to his native country, Poland. He was always ready to help the libraries/publishers/dealers in whatever way he could. He remained in close touch with developments in the book trade and in the Polish equivalent of knigovedenie. During the heady days of Solidarity, Wojciech was in the country, collecting materials and arranging for a microfilming camera to be sent to one of the libraries to film the prolific output of this important historical event. Stanford became one of the major collections in the U.S. documenting the Solidarity movement. Another major Polish contribution was his compilation of a bibliography of his friend, the Nobel prize winner for poetry Czeslaw Milosz: an International Bibliography, 1930-1980 (1983).

One of Wojciech's particular strengths was his good understanding of Slavic acquisitions. He always maintained close contact with book dealers, and was worried about their well-being. He often spoke up for the dealers at meetings of Slavic librarians, and felt it was our duty to support them by ordering from as many as possible. In the chaotic period after the collapse of the Soviet Union he tried to keep us 
informed of developments. He was concerned about the state of exchanges, currency devaluation, inflation, and how it affected our ability to collect the materials we needed.

It was during the first Slavic librarians' conference held at the University of Illinois (Urbana-Champaign) in September of 1975 that I first met Dr. Wojciech Zalewski, when I was seated across from him at lunch. Our many years of working together began when I wrote him in March 1976 for help with photocopying from two Polish encyclopedias; he replied within days with the photocopies and added he was "glad that our contact exists and that we are able to use our mutual services. Is it not a positive outcome of our Urbana meeting?"

The following year I attended my first AAASS convention in St. Louis. I had met Basil Dmytryshyn, a historian from Portland State U., for a drink or maybe two, but honestly I wasn't drunk. We walked into the hotel restaurant for dinner and as we neared our table the floor must have been wet. I slipped and was flat on my back looking straight up at the looming figure of Wojciech. At this early stage of my career, I was mortified to think I had fallen at the feet of the Curator of Stanford's Slavic Collection. But he never seemed to hold this against me.

In 1980 Wojciech began to write about organizing a West Coast Slavic Cooperative. Creating such a group actually meant reviving/ changing the moribund Pacific NW Slavic Cooperative. The idea finally became a reality in 1993, when meetings began which led to the establishment of the Pacific West Coast Slavic Consortium.

At the Western Slavic Association meeting in Honolulu in 1982, Wojciech made a proposal to start a journal for Slavic librarians. This eventually became the SEES Newsletter.

During the 1980s, when Edward Kasinec was Slavic Bibliographer at the University of California, Berkeley, it seemed as if Joe Dwyer (Hoover Institution), Wojciech, Ed and I were like the gang of four. We were always discussing many ideas. Although Wojciech was usually in a positive mood, in 1988 he wrote that he was "depressed about the non-collegiality of our group; we thrive on our inertia, we are split (ALA/AAASS/BIRD/IREX), and consequently we as a group are not consulted on anything and by anybody."

Perhaps the nicest part of the small Slavic library community is that many of us have gotten to know each other on a personal basis. Wojciech and his wonderful wife, Rosemarie, have welcomed me into their home many times. It was while staying with them in 1984 that 
word came that my brother had died. Rosemarie and I sat talking for many hours. Wojciech has a wonderful private library of fine printed books from Poland and Czechoslovakia in particular. Much of the correspondence from Wojciech is in his own writing with a fountain pen on nice paper. I thank Wojciech for years of friendship and professional inspiration.

\section{FROM JANET CRAYNE}

I could not come up with any particular anecdotes relating to Wojciech, or perhaps I simply didn't want to. Those little pieces of experience just didn't come close to illustrating how I feel about Wojciech. For the past fifteen years I have been amazed at his erudition. His knowledge of Slavic bibliography, history, religion and literature, both past and present, is quite remarkable. Although he used this knowledge regularly in his work, he never flaunted it. I know, because ever since I began in the field he, more than anyone else, not only provided the answers to my queries, but cited the references that I could use later. And as the years have gone by, he, already a resource and a mentor, became a friend. During the period of time when civil war had broken out in Former Yugoslavia, his words of encouragement made the difference between giving up, and pushing forward. I am not sure how these qualities could be separated out, in an area where we are all so close. It seems to me that they all reinforce each other, and forge multi-dimensional relationships in Slavic librarianship. For me, Wojciech is the epitome of all that I value in our field, because of what I said above and for his great sense of humor, his intelligence and experience. Wojciech is a terrific person and someone I am proud to call a colleague. I hope that for our sake he keeps his promise to maintain a profile among us. If he doesn't, then I fear we will suffer a terrible loss. Thank you, Wojciech, for being such a vital part of what Slavic librarianship in the United States is today.

\section{FROM LEON FERDER}

When I became a Slavic bibliographer and began attending ALA's SEES and AAASS B \& D meetings, I immediately became aware of Wojciech's stature, as other Slavic librarians looked to him for advice 
and guidance, whether for policy matters or technical questions. Wojciech's knowledge, experience and winning personality have earned him the respect and admiration of librarians, vendors and exchange partners throughout the Slavic and East European community. One of Wojciech's goals had long been to create a formal Slavic librarians' group on the West Coast. He never gave up, and after several less than successful attempts, was the guiding force behind the creation of the Pacific Coast Slavic and East European Library Consortium (PACSLAV) in 1996. Without Wojciech's ability to mobilize librarians and administrators at every level, the group could never have been formed. As its first chair, Wojciech made certain that PACSLAV became a productive entity by formulating and administering a number of significant projects. I happily join all who have had the pleasure of knowing and working with Wojciech Zalewski, in congratulating him and wishing him a healthy and productive retirement.

\section{FROM JANET ZMROCZEK}

In 1990 the ICSEES (International Council of Soviet and East European Studies) Conference in Harrogate and the preceding Librarians' conference in Cambridge were my first foray into the heady world of international conferences. It was with great trepidation that I prepared my paper for a panel on publishing and sent it off to the discussant, Wojciech Zalewski, whom I imagined as an august, distant figure likely to tear it to pieces. Reality could not have been more different. Wojciech's support, encouragement and friendship have been a great inspiration in my career. There is no doubt that his retirement will leave a huge gap, but by his dynamic 'can-do' approach to even the trickiest problems, his enthusiasm and his personal warmth he has given enormous encouragement to a whole new generation in the field of Slavic librarianship and his values will live on through us all.

\section{FROM MARIANNA TAX CHOLDIN}

I do not remember the exact date of our first meeting, but it must have been in the middle or late 1970s, when Anna Stuliglowa and I were working hard to involve as many North American librarians as 
possible in the activities of the AAASS Bibliography and Documentation Committee. Wojciech surfaced as one of the most active and hardworking colleagues, and he continued to fit this description throughout his career. He cared passionately about libraries and librarians in "our" region, with a special place in his heart-not surprisinglyfor Poland.

I worked closely with Wojciech on too many projects to count, but two in particular surface in my mind as I recall the last twenty-plus years. In 1980, at Wojciech's suggestion, the B \& D Committee began working rather feverishly on a plan to ask the AFL-CIO to donate photocopy machines to Solidarity so the movement could copy its literature. Part of the plan, of course, was to ensure that a copy of each brochure, flyer, booklet and broadsheet was deposited in a library. The advent of martial law put an abrupt stop to this project, but that was not Wojciech's fault: the idea was a splendid one.

The second project, on which we collaborated particularly closely, was the librarians' conference in Kraków preceding the 1995 World Congress of the International Council on Central and East European Studies (ICCEES, the successor to ICSEES) in Warsaw. This project was quite a complex undertaking: Wojciech had a grant from IREX to bring people to the preconference, and I had obtained funding from the Soros Network Library Program for librarians to attend the Congress. Most participants wanted to attend both events. It took dozens, if not hundreds, of e-mail messages, faxes and phone conversations to get everything straight with every participant and with the organizers in Kraków and Warsaw and work out funding arrangements before, during and after the event. Throughout, Wojciech maintained his sense of humor. That I recall the whole episode with pleasure rather than disgust is due in no small measure to Wojciech's personality. I shall remember our collaboration on these and many other projects, large and small, fondly, and I wish Wojciech a happy retirement. 